\title{
Development of Plants in Combination of Products Associated with the Inoculation in the Soybeans Seeds Treatment
}

\author{
Everton Vinicius Zambiazzi ${ }^{1}$, Adriano Teodoro Bruzi ${ }^{1}$, Frederico Dellano Souza Silva ${ }^{1}$, Eric Vinicius Vieira Silva ${ }^{1}$, \\ Alan Mario Zuffo ${ }^{2}$, Scheila Roberta Guilherme ${ }^{3}$, Fiorita Faria Monteiro ${ }^{1}$, Alan Eduardo Seglin Mendes ${ }^{1}$, \\ Antônio Henrique Fonseca de Carvalho ${ }^{1} \&$ Maria Laene Moreira de Carvalho ${ }^{1}$ \\ ${ }^{1}$ Department of Agriculture, Federal University of Lavras, University Campus, Lavras, Minas Gerais, Brazil \\ ${ }^{2}$ Department of Crop Production, State University of Mato Grosso do Sul, Cassilândia, Mato Grosso do Sul, \\ Brazil \\ ${ }^{3}$ Department of Biology, Federal University of Lavras, University Campus, Lavras, Minas Gerais, Brazil \\ Correspondence: Alan Mario Zuffo, Department of Crop Production, State University of Mato Grosso do Sul, \\ Cassilândia, Mato Grosso do Sul, Brazil. E-mail: alan_zuffo@hotmail.com
}

Received: June 20, 2017

doi:10.5539/jas.v9n9p123
Accepted: July 18, $2017 \quad$ Online Published: August 15, 2017

URL: https://doi.org/10.5539/jas.v9n9p123

\begin{abstract}
The purpose of this study was to evaluate the effect of different combinations of products applied through seed treatment, associated with the inoculation, in the development of soybean plants. The experiment was conducted in a greenhouse at Federal University of Lavras (UFLA). The experimental design was a randomized complete block, with four repetitions in a factorial $4 \times 11$, being four soybean cultivars and 11 combinations of products associated with the inoculation in the treatment of seeds. At the stage $\left(R_{1}\right)$ it was evaluated: plant height, leaf area, foliar chlorophyll content, number of trifoliate leaves, dry shoot mass, dry root mass, root length, root volume, nodules total number, viable nodules total number, nodules dry mass and foliar nitrogen content. The combination of products in the treatment of seeds, do not present phytotoxic effects in the characters related to the development, except for dry matter of aerial part and root volume. The combination of products in treatment of seeds influences negatively the nodulation, especially in the treatments with presence of nematicide. The inoculation performed in isolation or combined with fungicide and insecticide (I+FI) maintains nodule levels.
\end{abstract}

Keywords: Glycine max (L.), biological fixation, phytotoxicity, nodules

\section{Introduction}

The success of soybean production (Glycine max L. Merrill) is related to the competitive capacity associated with scientific advances and the availability of technologies to the productive sector (Hungria et al., 2005), as well as by the correct use of diverse cultural practices. In this sense, the introduction of bacteria genus Bradyrhizobium, which performs the biological nitrogen fixation (BNF), was one of the main boosters of large-scale soybean cultivation in Brazil (Zuffo et al., 2015). This feature makes soybean cultivation viable, since, without BNF, about $240 \mathrm{~kg} \mathrm{ha}^{-1}$ of $\mathrm{N}$ for a production of $3000 \mathrm{~kg} \mathrm{ha}^{-1}$, which would cause a significant increase in the cost of production of soybean (Hungria et al., 2001).

Several other technologies have also been studied, aiming at best productive results for the soybean crop, for example, the treatment of seeds, for the improvement and maintenance of seed quality (Cunha et al., 2015), providing uniform stands. The use of seeds treated through the use of certain products has been a safe and relatively inexpensive way of practicing the control of numerous pests and diseases whose causal agents are transmitted by seeds or even inhabitants of the soil (Venegas et al., 2011).

The treatment of soybean seeds is an indicated technique since it is used products in the recommended dosage and evenly distributed in the seeds (Avelar et al., 2011), as well as being able to eradicate pests and pathogens present in seed, it is not toxic to plants, environment and human beings, in addition to presenting high stability, adhesion and coverage, it is not corrosive, be of low cost and easy to acquire (Peske et al., 2006), and provide compatibility with other products so that their mixtures do not interfere negatively on the seeds (Almeida et al., 2014). 
As the perception of the value of the seed increases and the importance of protecting and improving its performance, It grows in the market the availability of products for the treatment of seeds, with different purposes, such as the biological nitrogen fixation (inoculant), protection and control of pests and diseases (fungicides, insecticides or nematicides), nutrition (micronutrients), and rooting compounds, to improve seed performance both physiologically and economically (Avelar et al., 2011).

Although seed treatment is a practice already established and routinely performed by producers, it has also a deficiency on a thorough understanding of the influence of several chemicals and biological products offered by the market, on the development of the crop (Souza et al., 2015). In the production of the soybean crop, which aims to high yields, many products are recommended as nutritional additives, synthetic hormones, among others, for use in seed treatment (Souza et al., 2015). As a greater supply of products on the market is observed, the number of combinations of products to the same seed has increased in recent years. The mixture of products has been recommended allowing to increase the number of targets to be controlled (Menten \& Moraes, 2010; Juliatti, 2010).

The use of products in combination may compromise the development of the plants to be produced (Follmann et al., 2014). On the other hand some studies in the literature have shown that even in the absence or at low levels of harmful organisms to the crop, the combination of products has improved the development of cultures, with greater vigor of plants, impacting positively on the grain yield (Ceccon et al., 2004).

Several studies have been conducted with the combination of products; however, they restrict the combination of few products in associated with the inoculation, which does not report the current situation of seed treatment performed by producers. Given the above, this study aimed to evaluate the effect of different combinations of products applied through seed treatment, together with the inoculation on the vegetative development of soybean plants.

\section{Material and Methods}

\subsection{Location and Characterization of the Experimental Area}

The study was conducted in a controlled environment (greenhouse), with a temperature of $27 \pm 2{ }^{\circ} \mathrm{C}$ and relative air humidity of $80 \pm 2 \%$, in the crop science department at Lavras Federal University (UFLA) in Lavras, Minas Gerais, Brazil $\left(21^{\circ} 12^{\prime} \mathrm{S}\right.$ and $44^{\circ} 58^{\prime} \mathrm{W}$, with an altitude of $\left.918 \mathrm{~m}\right)$, from November 2016 to January 2017. The climate of the region is Cwa type, with annual average temperature of $19.3{ }^{\circ} \mathrm{C}$ and normal annual precipitation of $1.530 \mathrm{~mm}$ (Dantas et al., 2007).

The substrate used was removed from an area with no agriculture history, in which presents the chemical composition of $2.40 \mathrm{~g} \mathrm{~kg}^{-1}$ of organic matter equivalent; $5.49 \mathrm{of} \mathrm{pH}\left(\mathrm{CaCl}_{2}\right) ; 0.88$ and 20.08 respectively for $\mathrm{P} \mathrm{e}$ $\mathrm{K} \mathrm{mg} \mathrm{dm}{ }^{-3} ; 0.33,0.11,0.10,2.91$, and 0.47 respectively for $\mathrm{Ca}, \mathrm{Mg}, \mathrm{Al}$, potential acidity $(\mathrm{H}+\mathrm{Al})$ and sum of bases (SB) $\mathrm{cmol} \mathrm{dm}^{-3} ; 3.37$ cation exchange capacity (CEC) at $\mathrm{pH} 7.0 ; 23.96 \%$ for base saturation (V) The soil is classified as a typical Dystrophic Red Latosol, according to the Brazilian System of Soil Classification (Santos et al., 2013a), which presents clayey texture (65\%), being added sand in the ratio $1: 2 \mathrm{v} / \mathrm{v}$, respectively.

The lime recommendation was performed according to the method of saturation with oxygen saturation ideal the level of $70 \%$. The dose per hectare was transformed to the volume of the nursery pot. First, the lime was added to the substrate and allowed to stand for 30 days, during this period the soil was mixed up and irrigated. Subsequently, the substrate was placed in nursery pots and then held the fertilization. The nutrients phosphorus $(\mathrm{P})$, potassium $(\mathrm{K})$ and sulfur $(\mathrm{S})$ were provided in doses of $200 \mathrm{mg} / \mathrm{dm}^{3}, 150 \mathrm{mg} / \mathrm{dm}^{3}$ and $50 \mathrm{mg} / \mathrm{dm}^{3}$, respectively, as recommended by Malavolta (1980) and Novais et al. (1991). In addition, K was provided through 'potassium chloride' and the P and S by a type of superphosphate, called "super simples".

\subsection{Experimental Design}

The experimental design was a randomized complete block with four repetitions, arranged in a factorial scheme $4 \times 11$, being composed of four soybean cultivars (M 5917 IPRO, M 5947 IPRO, M 6410 IPRO and Produza IPRO) and eleven different combinations of fungicides, insecticides, nematicides, micronutrients and rooting compounds associated with the inoculation in the treatment of soybean seeds. The seed treatment consisted in: 1) Control (no treatment); 2) Inoculant; 3) Inoculant + rooting compound; 4) Inoculant + fungicide and insecticide; 5) Inoculant + micronutrient; 6) Inoculant + nematicide; 7) Inoculant + fungicide and insecticide + rooting compound; 8) Inoculant + fungicide and insecticide + micronutrient; 9) inoculant + fungicide and insecticide + micronutrient + rooting compound; 10) Inoculant + fungicide and insecticide + micronutrient + nematicide; 11) Inoculant + fungicide and insecticide + micronutrient + nematicide + rooting compound. 


\subsection{Conducting the Experiment}

The products used were: Nitragin Cell Tech $\mathrm{HC}^{\circledR}$ liquid inoculant with bacteria of the genus Bradyrhizobium japonicum, containing SEMIA strains 5079 and 5080 (minimum concentration of $3 \times 10^{9} \mathrm{CFU}$ per mL), $300 \mathrm{~mL}$ p.c. $/ 100 \mathrm{~kg}^{-1}$ of seeds; fungicide and insecticide: pyraclostrobin + thiophanate methyl + Fipronil (Standak ${ }^{\circledR}$ Top), $100 \mathrm{~g}$ a.i. $/ 100 \mathrm{~kg}^{-1}$ of seed; fertilization of liquid formulation Mo: $17.5 \%, \mathrm{Co}: 1 \%$ (CoMo Plus 250 ), at a dose of $200 \mathrm{~mL}$ p.c. $/ 100 \mathrm{~kg}^{-1}$ of seed; rooting compound (Arrimo), $1 \mathrm{~kg}$ p.c. $/ 100 \mathrm{~kg}$ of seeds and nematicide Abamectin (Avicta $500 \mathrm{FS}$ ), $125 \mathrm{~mL}$ p.c. $/ 100 \mathrm{~kg}^{-1}$ of seed.

The products were previously mixed in Becker and placed in plastic bags with a capacity of three liters, using 500 grams of seed. The set was stirred until homogeneous mixtures of seeds were obtained. After the treatment, the seeds were placed in the shade for 2 hours, for drying of products on the surface of the seed. After this period, the seeds were inoculated with bacteria of the genus Bradyrhizobium japonicum, whose bacterial concentration is $3 \times 10^{9} \mathrm{UFC}$ per $\mathrm{mL}$.

Four seeds were sown in each pot, with a capacity of $12 \mathrm{dm}^{-3}$, at a depth of 1-2 cm. Subsequently, thinning was performed, leaving two plants per pot. During the development of the plants weed control was done manually, with no need for control of pests and diseases. Irrigation was performed in order to maintain the water content in the soil with $2 / 3$ of the field capacity.

\subsection{Measuring of Variables}

When the soybean plants were at the reproductive stage $\mathrm{R}_{1}$ (beginning of flowering), they were collected for the evaluations of the effectiveness of biological nitrogen fixation, through nodulation in accordance with Hungria et al. (1997). It was also evaluated the characters:

Plant height $(\mathrm{cm})$ : determined from the surface of the substrate to the insertion of the last leaf with the aid of a millimeter rule;

Foliar area $\left(\mathrm{cm}^{2}\right)$ : collected from each plant, the petiole was removed, subsequently, the leaves were placed under a sheet of A4 paper white, and photographed with a digital camera (Samsung WB350F and resolution of 72 dpi (dots per inch). The images were processed by the Software Image ${ }^{\circledR}$ (Powerful Image Analysis) (Collins, 2007). The images of leaves were captured by procedures of color contrast (being the dark colored leaf and contrasting white background), and, through the comparison with the actual scale present, it was determined the leaf area average;

Foliar chlorophyll content: We used the chlorophyll meter (clorofilLOG CFL 1030), together with an evaluation of the third trefoil developed from top to bottom, measuring 3 different points in each trifolium, always in the leaf limb between the midribs;

Number of trifoliate leaves: performed by visual counting;

Dry mass shoot/root (g): the plants were separated into shoot and root system, packed in paper bags and taken to a forced circulation oven for 72 hours at $60{ }^{\circ} \mathrm{C}\left( \pm 1.0^{\circ} \mathrm{C}\right)$, aiming at the determination of the dry mass of roots and shoots, weighed in analytical balance with a precision of $0.0001 \mathrm{~g}$.

Root volume $\left(\mathrm{cm}^{3}\right)$ : determined by water displacement method, using a measuring cylinder of $100 \mathrm{~mL}$ graduated in milliliters $(\mathrm{mL})$, therefore, with accuracy of $\pm 1.0 \mathrm{~cm}^{3}$;

Root length $(\mathrm{cm})$ : After washing and drying, the roots were placed under a sheet of white A4 paper, and photographed with a digital camera (Samsung WB350F and resolution of 72 dpi (dots per inch). The images were processed by the Software Image ${ }^{\circledR}$ (Powerful Image Analysis) (Collins, 2007). The images were captured and, by comparison, with the actual scale presented, the root length was determined;

Number of total nodules (unit): the roots were carefully removed from the nursery pot and then washed in water over a sieve, avoiding the loss of nodules. Then the nodules were detached and counted in each plant, obtaining the average value of nodules;

Number of viable nodules (unit): The highlighted nodules from roots after total nodule counts were cut in half with the help of scalpel, for internal color observation, which presented a pink color or reddish color indicating symbiotic efficiency. Then the viable nodules were counted in each plant, obtaining the average value;

Dry mass of nodules $(\mathrm{mg})$ : the total nodules were packed in paper bags and taken to a forced circulation oven for 72 hours at $60{ }^{\circ} \mathrm{C}\left( \pm 1.0^{\circ} \mathrm{C}\right)$ and weighed in analytical balance with a precision of $0.0001 \mathrm{~g}$, whereby the dry mass of the nodules is obtained; 
Nitrogen content (\%): The third or fourth leaf was sampled from the apex of the main stem and taken to a forced circulation oven for 72 hours at $60{ }^{\circ} \mathrm{C}\left( \pm 1.0^{\circ} \mathrm{C}\right)$. Subsequently, this material was ground into Wiley mill equipped with sieve mesh size 40 , and the determination of leaf $\mathrm{N}$ was performed by the semi-micro analytical Kjeldahl method, after sulfur digestion.

\subsection{Experimental Statistical Analyses}

After collection and tabulation of data, we performed the analysis of variance (ANOVA), and when significant means were grouped by Scott Knott at $5 \%$ of probability, using the statistical program SISVAR $^{\circledR}$ version 5.3 for Windows (Software of Statistical Analyzes, UFLA, Lavras, MG, BRASIL).

\section{Results and Discussions}

According to the results of the analysis of variance, there were statistical differences between the cultivars $(\mathrm{p}<$ 0.01) in all evaluated characters (Table 1). Plant height, leaf area, root volume, number of total nodules, total number of viable nodules, nodule dry mass and leaf nitrogen content were significantly $(\mathrm{p}<0.01)$ influenced by seed treatment. Similar results were obtained by Conceição et al. (2014) and Cunha et al. (2015), where the authors found no significant effect of seed treatment on soybean development.

Table 1. Variance analysis summary for plant height (PH - cm), leaf area (LA), chlorophyll content (CC), number of trifoliate leaves (TL), dry mass shoot (DS), dry mass root (DR), root length (RL), root volume (RV), total number nodules (TN), number of viable nodules (VN), nodules dry mass (ND) and foliar nitrogen content (NC) for the soybean cultivars (C) and combinations of products in seeds treatment (ST). Lavras, MG, Brazil, 2017

\begin{tabular}{|c|c|c|c|c|c|c|c|c|c|c|c|c|c|}
\hline \multirow{2}{*}{ SV } & \multirow{2}{*}{ DF } & \multicolumn{12}{|c|}{ prob $>F c$} \\
\hline & & $\mathrm{PH}$ & LA & $\mathrm{CC}$ & $\mathrm{TL}$ & DS & DR & RL & RV & TN & $\mathrm{VN}$ & ND & $\mathrm{NC}$ \\
\hline $\mathrm{C}$ & 3 & ** & $* *$ & $* *$ & $* *$ & $* *$ & $* *$ & $* *$ & $* *$ & ** & $* *$ & $* *$ & $* *$ \\
\hline ST & 10 & $* *$ & $* *$ & NS & NS & $* *$ & NS & NS & $* *$ & $* *$ & $* *$ & $* *$ & $* *$ \\
\hline $\mathrm{C} \times \mathrm{ST}$ & 30 & NS & NS & NS & NS & NS & NS & NS & NS & NS & NS & NS & NS \\
\hline $\mathrm{CV}$ & & 7.5 & 11.1 & 4.3 & 10.9 & 13.0 & 18.5 & 9.8 & 9.7 & 16.4 & 19.5 & 14.0 & 10.0 \\
\hline GA & & 23.3 & 28.5 & 28.7 & 8.7 & 1.7 & 2.5 & 56.3 & 38.7 & 34.2 & 26.2 & 0.15 & 2.2 \\
\hline
\end{tabular}

Note. $($ prob $>F c)$ : ** Significant at $1 \%(<0.01),{ }^{*}$ Significant at $5 \%(<0.05)$, and (NS) Not significant according to the F. Average tests followed by the same letter, in column, do not differ from each other, at $5 \%$ probability by the Scott Knott test. CV: Coefficient of Variation (\%). GA: General Average. Fc: F calculated.

For cultivars evaluated, we observed a higher plant height, foliar chlorophyll content and dry shoot mass to the cultivar Produza IPRO (Table 2), however greater leaf area was observed for the cultivars M 5917 IPRO and M 5947 IPRO. The cultivar with lowest development of leaflets was the M 5917 IPRO, with an average of eight trifoliate leaves. These variations are related to differences in genetic background, growth habit, and other attributes (Soares et al., 2015; Felisberto et al., 2015). 
Table 2. Phenotypic average of plant height $(\mathrm{PH}-\mathrm{cm})$, leaf area $\left(\mathrm{LA}-\mathrm{cm}^{2}\right)$, chlorophyll content $(\mathrm{CC}-\mathrm{SPAD}$ index), number of trifoliate leaves (TL), dry mass shoot (DS - g), dry mass root (DR - g), root length (RL - cm), root volume $\left(\mathrm{RV}-\mathrm{cm}^{3}\right)$, total number nodules $(\mathrm{TN})$, number of viable nodules $(\mathrm{VN})$, nodules dry mass $(\mathrm{ND}-\mathrm{mg})$ and foliar nitrogen content ( $\mathrm{NC}-\%)$ for the soybean cultivars (C) and combinations of products in seeds treatment (ST). Lavras, MG, Brazil, 2017

\begin{tabular}{lcccccccccccc}
\hline & PH & LA & CC & TL & DS & DR & RL & RV & TN & VN & ND & NC \\
\hline Cultivars (C) & & & & & & & & & & & & \\
M 5917 IPRO & $21.2 \mathrm{c}$ & $29.0 \mathrm{a}$ & $28.5 \mathrm{~b}$ & $8 \mathrm{~b}$ & $1.4 \mathrm{~d}$ & $2.3 \mathrm{c}$ & $56.2 \mathrm{a}$ & $35.3 \mathrm{~b}$ & $33 \mathrm{~b}$ & $27 \mathrm{a}$ & $0.17 \mathrm{a}$ & $2.3 \mathrm{a}$ \\
M 5947 IPRO & $22.2 \mathrm{~b}$ & $29.5 \mathrm{a}$ & $28.7 \mathrm{~b}$ & $9 \mathrm{a}$ & $1.7 \mathrm{~b}$ & $2.2 \mathrm{c}$ & $57.6 \mathrm{a}$ & $36.1 \mathrm{~b}$ & $39 \mathrm{a}$ & $28 \mathrm{a}$ & $0.15 \mathrm{~b}$ & $2.2 \mathrm{~b}$ \\
M 6410 IPRO & $22.6 \mathrm{~b}$ & $28.0 \mathrm{~b}$ & $28.4 \mathrm{~b}$ & $9 \mathrm{a}$ & $1.6 \mathrm{c}$ & $2.5 \mathrm{~b}$ & $59.0 \mathrm{a}$ & $37.1 \mathrm{~b}$ & $38 \mathrm{a}$ & $28 \mathrm{a}$ & $0.13 \mathrm{c}$ & $2.1 \mathrm{~b}$ \\
Produza IPRO & $27.1 \mathrm{a}$ & $27.3 \mathrm{~b}$ & $29.3 \mathrm{a}$ & $9 \mathrm{a}$ & $2.0 \mathrm{a}$ & $3.0 \mathrm{a}$ & $52.2 \mathrm{~b}$ & $46.3 \mathrm{a}$ & $27 \mathrm{c}$ & $22 \mathrm{~b}$ & $0.14 \mathrm{~b}$ & $2.3 \mathrm{a}$ \\
\hline Seeds Treatment & $(S T)$ & & & & & & & & & & \\
C & $21.0 \mathrm{~b}$ & $25.3 \mathrm{~b}$ & $27.9 \mathrm{a}$ & $8 \mathrm{a}$ & $1.3 \mathrm{c}$ & $2.3 \mathrm{a}$ & $59.4 \mathrm{a}$ & $37.9 \mathrm{~b}$ & $36 \mathrm{~b}$ & $28 \mathrm{~b}$ & $0.15 \mathrm{a}$ & $2.1 \mathrm{~b}$ \\
I & $21.9 \mathrm{~b}$ & $28.1 \mathrm{a}$ & $28.6 \mathrm{a}$ & $8 \mathrm{a}$ & $1.9 \mathrm{a}$ & $2.3 \mathrm{a}$ & $54.2 \mathrm{a}$ & $40.2 \mathrm{a}$ & $40 \mathrm{a}$ & $32 \mathrm{a}$ & $0.15 \mathrm{a}$ & $2.3 \mathrm{a}$ \\
I+E & $24.2 \mathrm{a}$ & $28.4 \mathrm{a}$ & $28.2 \mathrm{a}$ & $9 \mathrm{a}$ & $1.8 \mathrm{a}$ & $2.7 \mathrm{a}$ & $56.6 \mathrm{a}$ & $41.5 \mathrm{a}$ & $34 \mathrm{~b}$ & $26 \mathrm{~b}$ & $0.14 \mathrm{a}$ & $2.3 \mathrm{a}$ \\
I+FI & $24.0 \mathrm{a}$ & $28.2 \mathrm{a}$ & $28.7 \mathrm{a}$ & $9 \mathrm{a}$ & $1.8 \mathrm{a}$ & $2.8 \mathrm{a}$ & $56.8 \mathrm{a}$ & $40.1 \mathrm{a}$ & $39 \mathrm{a}$ & $32 \mathrm{a}$ & $0.15 \mathrm{a}$ & $2.3 \mathrm{a}$ \\
I+M & $23.1 \mathrm{a}$ & $29.3 \mathrm{a}$ & $29.2 \mathrm{a}$ & $9 \mathrm{a}$ & $1.6 \mathrm{~b}$ & $2.5 \mathrm{a}$ & $54.3 \mathrm{a}$ & $41.1 \mathrm{a}$ & $34 \mathrm{~b}$ & $26 \mathrm{~b}$ & $0.16 \mathrm{a}$ & $2.3 \mathrm{a}$ \\
I+N & $23.4 \mathrm{a}$ & $28.2 \mathrm{a}$ & $29.0 \mathrm{a}$ & $9 \mathrm{a}$ & $1.6 \mathrm{~b}$ & $2.4 \mathrm{a}$ & $56.3 \mathrm{a}$ & $38.6 \mathrm{a}$ & $28 \mathrm{c}$ & $19 \mathrm{c}$ & $0.14 \mathrm{~b}$ & $2.0 \mathrm{~b}$ \\
I+FI+E & $24.8 \mathrm{a}$ & $29.3 \mathrm{a}$ & $29.2 \mathrm{a}$ & $9 \mathrm{a}$ & $1.9 \mathrm{a}$ & $2.5 \mathrm{a}$ & $54.2 \mathrm{a}$ & $41.5 \mathrm{~b}$ & $36 \mathrm{~b}$ & $29 \mathrm{~b}$ & $0.16 \mathrm{a}$ & $2.3 \mathrm{a}$ \\
I+FI+M & $23.4 \mathrm{a}$ & $28.2 \mathrm{a}$ & $28.7 \mathrm{a}$ & $9 \mathrm{a}$ & $1.7 \mathrm{~b}$ & $2.6 \mathrm{a}$ & $56.8 \mathrm{a}$ & $33.4 \mathrm{c}$ & $36 \mathrm{~b}$ & $28 \mathrm{~b}$ & $0.15 \mathrm{a}$ & $2.3 \mathrm{a}$ \\
I+FI+M+E & $23.0 \mathrm{a}$ & $28.2 \mathrm{a}$ & $28.8 \mathrm{a}$ & $9 \mathrm{a}$ & $1.6 \mathrm{~b}$ & $2.6 \mathrm{a}$ & $55.3 \mathrm{a}$ & $34.8 \mathrm{c}$ & $35 \mathrm{~b}$ & $28 \mathrm{~b}$ & $0.15 \mathrm{a}$ & $2.4 \mathrm{a}$ \\
I+FI+M+N & $23.8 \mathrm{a}$ & $29.8 \mathrm{a}$ & $29.3 \mathrm{a}$ & $9 \mathrm{a}$ & $1.7 \mathrm{~b}$ & $2.7 \mathrm{a}$ & $54.7 \mathrm{a}$ & $38.8 \mathrm{~b}$ & $29 \mathrm{c}$ & $20 \mathrm{c}$ & $0.12 \mathrm{~b}$ & $2.1 \mathrm{~b}$ \\
I+FI+M+N+E & $23.7 \mathrm{a}$ & $30.1 \mathrm{a}$ & $28.7 \mathrm{a}$ & $9 \mathrm{a}$ & $1.6 \mathrm{~b}$ & $2.6 \mathrm{a}$ & $57.4 \mathrm{a}$ & $37.7 \mathrm{~b}$ & $30 \mathrm{c}$ & $22 \mathrm{c}$ & $0.12 \mathrm{~b}$ & $2.0 \mathrm{~b}$
\end{tabular}

Note. Seed Treatment: C: Control (No treatment); (I) Inoculant; (FI) fungicide and insecticide; (M) micronutrient; (N) nematicide and (R) rooting compound. T1: (C); T2: (I); T3: (I+R); T4: (I+FI); T5: (I+M); T6: (I+N); T7: (I+FI+R); T8: (I+FI+M); T9: (I+FI+M+R); T10: (I+FI+M+N) e T11: (I+FI+M+N+R).

In relation to the root length, the highest values were for the cultivars M 5917 IPRO, M 5947 IPRO, M 6410 IPRO, who showed 56.28, 57.67 and $59.05 \mathrm{~cm}$, respectively (Table 2). However, higher dry mass shoot/root and the root volume were observed for the cultivar Produza IPRO, which can probably be explained by the higher developments of lateral roots in relation to the main root length (pivoting) in this cultivar.

For the character number of nodules and total number of viable nodules was observed lower nodulation for both characteristics when used the cultivar produza IPRO, respectively with 27 and 22 nodules, which represents a nodulation $31 \%$ below the other cultivars, which had a direct result on the dry mass of nodules $(0.144 \mathrm{mg})$, one of the lowest presented among the cultivars studied.

However, the highest leaf nitrogen content was observed for the cultivars M 5917 IPRO and Produza IPRO, which despite having a lower number of total nodes, obtained a higher nodule/total nodule dry mass ratio with 0.0051 and $0.0053 \mathrm{mg} /$ node respectively, when compared the cultivars M 5947 IPRO (0.0038 $\mathrm{mg} / \mathrm{node})$ and M 6410 IPRO ( $0.0035 \mathrm{mg} /$ node), that is, the nodules of cultivars M 5917 IPRO and Produza IPRO were in smaller numbers, even though bigger. According to Hungria et al. (2001) in addition to the number of nodules, it is essential to check the size of the nodules, since it is desirable to have nodules with size equal to or greater than 2 $\mathrm{mm}$, which are the nodules with the greatest $\mathrm{N}_{2}$ fixation capacity.

For the source of variation in seed treatment, differences were observed between treatments for plant height, leaf area, and root volume, number of nodules, total number of viable nodules, nodule dry mass and leaf nitrogen content (Table 2). It is observed that the association of the products in the treatment of seeds, promoted an increase in plant height and foliar area of plants, obtaining values higher than those found for the control and also for the treatment in the presence of inoculation in an isolated way. According to Taiz and zeiger (2012), the use of these products in the treatment of seeds tend to modulate the cellular processes, interacting with specific proteins called receptors, enabling the plants to have a better development, making them more vigorous.

For the variables of foliar chlorophyll content, number of trifoliate leaves, dry mass root and root length, no difference was observed between the evaluated treatments (Table 2), which shows that the combination of different products in the treatment of seeds was not harmful to the development of plants for these variables. 
Absence of phytotoxic effect was also observed by Cunha et al. (2015) and Balardin et al. (2011), who evaluated the effect of seed treatment on the development of soybean plants, for the same variables studied. According to Conceição et al. (2014), these results point out the efficiency of seed treatment, though in order to be considered effective; it must not have phytotoxic effect on the physiological quality of the seeds, as well as the development of the plants.

However, for the variable dry mass shoot (Table 2), the best performance of plants were obtained when used the treatments inoculated with isolated form (I) and the combination of the inoculation with fungicide + insecticide $(\mathrm{I}+\mathrm{FI})$ and rooting compound $(\mathrm{I}+\mathrm{R})$ or by a combination of all of these products $(\mathrm{I}+\mathrm{FI}+\mathrm{R})$. Similar results were observed by Balardin et al. (2011), evaluating the dry mass shoot of soybean plants. However, for the variable in question Cunha et al. (2015) found no difference between the treatments. For the root volume (Table 2), it was observed higher ratio in plants that contained the inoculation treatments in an isolated form (I) and the combination of inoculation with fungicide and insecticide (I+FI), micronutrient (I+M), nematicide (I+N) and rooting compound (I+R). Similar results were observed by Dan et al., (2010) where the use of products in an isolated seed treatment way, allowed to obtain better results, when compared with combination products, nevertheless evaluating the seed quality.

When we evaluated the number of total nodules, number of viable nodules, nodule dry mass and leaf nitrogen concentration (Table 2), it was possible to observe that the greatest number of nodules and total viable were obtained when used the treatments inoculated in isolated form (I) and the combination of inoculation with fungicide and insecticide (I+FI). For the remaining treatments, there was a phyto-toxic effect, which resulted in a reduction in the number of total nodules and viable nodules, with special emphasis on treatments that showed nematicide $(\mathrm{N})$, either isolated or combined with other active ingredients, with inhibition of total nodes close to $30 \%$ and $40 \%$ for viable nodules.

With the reduction in the number of total and viable nodules caused in treatments with nematicide (N), they also presented lower dry mass of nodules and lower leaf nitrogen content, reaching values of leaf nitrogen content lower than those found in the control (C) in which seed inoculation was not performed (Table 2). Similar results were obtained by Santos et al. (2013b), evaluating the effect of seed treatment on nodulation and initial growth of soybean crop, where the treatment of seeds in the presence of nematicides caused inhibition in the number of nodules.

The inhibition of the number of nodules may be related with the active principles, as well as the inert of these products used in the treatment of seeds, or even the changes in the $\mathrm{pH}$ of the spray mix in contact with the soil, when applied to the soil, or in the formulation of seed treatment, which includes in addition to the fungicides, insecticides and inoculant, and many times are increased with nutrients, growth regulators or resistance inducers, products capable of making $\mathrm{pH}$ more acid and spray mix more harmful to the diazotrophic bacteria (Silva et al., 2011).

In the control treatment (C), in which the inoculation of seeds with the bacteria Bradyrhizobium japonicum, was not carried out, it is noticed that the plants have developed and presented nodulation. Probably, this fact is related to the native bacteria in the soil, besides the organic matter present in the soil, since removal and stirring of the soil in order to mix the lime, there is an increase of sites of exposure to microbial attack and subsequent mineralization as reported by Miranda and Macedo (2001). The presence of nodules even in the absence of inoculation was also verified by Zuffo et al. (2015). It is suggested low efficiency of the nodulation present in the control treatment $(\mathrm{C})$, since, the results were mostly lower to the parameters evaluated, except for the treatments with presence of nematicides, where there was a phyto-toxic effect of this product, reducing the number of nodules below the control treatment for the number of total nodules, number of viable nodules and nodule dry mass (Table 2).

\section{Conclusions}

The combination of products in the treatment of seeds with the products tested, do not present phytotoxic effects in the characters related to the development, except for dry matter of aerial part and root volume. The combination of products in treatment of seeds influences negatively the nodulation, especially in the treatments with presence of nematicide. The inoculation performed in isolation or combined with fungicide and insecticide $(\mathrm{I}+\mathrm{FI})$ maintains nodule levels. 


\section{References}

Almeida, A. S., Castellanos, C. I. S., Deuner, C., Borges, C. T., \& Meneghello, G. E. (2015). Efeitos de inseticidas, fungicidas e biorreguladores na qualidade fisiológica de sementes de soja durante o armazenamento. Brazilian Journal of Agriculture-Revista de Agricultura, 89(3), 172-182.

Avelar, S. A. G., Baudet, L., Peske, S. T., Ludwig, M. P., Rigo, G. A., Crizel, R. L., \& Oliveira, S. (2011). Storage of soybean seed treated with fungicide, insecticide and micronutrient and coated with liquid and powered polymer. Ciência Rural, 41(10), 1719-1725. https://doi.org/10.1590/S0103-84782011005000130

Balardin, R. S., Silva, F. D. L., Debona, D., Dalla Corte, G., Favera, D. D., \& Tormen, N. Ã. (2011). Tratamento de sementes com fungicidas e inseticidas como redutores dos efeitos do estresse hidrico em plantas de soja. Ciência Rural, 41(7), 1120-1126. https://doi.org/10.1590/s0103-84782011000700002

Ceccon, G., Raga, A., Duarte, A. P., \& Siloto, R. C. (2004). Efeito de inseticidas na semeadura sobre pragas iniciais e produtividade de milho safrinha em plantio direto. Bragantia, 63, 227-237. https://doi.org/ $10.1590 / \mathrm{s} 0006-87052004000200008$

Collins, T. J. (2007). ImageJ for microscopy. BioTechniques, 43(1), 25-30. https://doi.org/10.2144/000112517

Conceição, G. M., Barbieri, A. P. P., Lúcio, A. D. C., Martin, T. N., Mertz, L. M., Mattioni, N. M., \& Lorentz, L. H. (2014). Desempenho de plântulas e produtividade de soja submetida a diferentes tratamentos químicos nas sementes. Bioscience Journal, 30(6), 1711-1720.

Cunha, R. P., Corrêa, M. F., Schuch, L. O. B., Oliveira, R. C., Junior, J. D. S. A., Da Silva, J. D. G., \& De Almeida, T. L. (2015). Diferentes tratamentos de sementes sobre o desenvolvimento de plantas de soja. Ciência Rural, 45(10), 1761-1767. https://doi.org/10.1590/0103-8478cr20140742

Dan, L. G. M., Dan, H. A., Barroso, A. L. L., Câmara, A. C. F., \& Guadanin, E. C. (2010). Efeito de diferentes inseticidas sobre a qualidade fisiológica de sementes de soja. Global Science and Technology, 3(1), 50-57.

Dantas, A. A., Carvalho, L. G., \& Ferreira, E. (2007). Classificação e tendências climáticas em Lavras, MG. Ciência e Agrotecnologia, 31(6), 1862-1866. https://doi.org/10.1590/s1413-70542007000600039

Embrapa (Empresa Brasileira de Pesquisa Agropecuária). (2013). Sistema brasileiro de classificação de solos (3rd ed., p. 353). Brasília.

Felisberto, G., Bruzi, A. T., Zuffo, A. M., Zambiazzi, E. V., Soares, I. O., Rezende, P. M., \& Botelho, F. B. S. (2015). Agronomic performance of RR soybean cultivars using to different pre-sowing desiccation periods and distinct post-emergence herbicides. African Journal Agriculture Research, 10(34), 3445-3452. https://doi.org/10.5897/ajar2015.9853

Follmann, D. N., Souza, V. Q., Nardino, M., Carvalho, I. R., \& Demari, G. H. (2104). Diferentes associações para aditivos em pré-semeadura na cultura da soja e seus efeitos sobre a qualidade das sementes produzidas. Enciclopédia Biosfera, 10(18), 1284-1292.

Hungria, M., Campo, R. J., \& Mendes, I. C. (2001). Fixação biologica do nitrogenio na cultura da soja (Circular Técnica, 35, p. 48). Londrina: Embrapa Soja.

Hungria, M., Franchini, J. C., Campo, R. J., \& Graham, E. P. H. (2005). The Importance Of Nitrogen Fixation To Soybean Cropping In South America. In D. Werner \& W. E. Newton (Eds.), Nitrogen fixation in agriculture: forestry ecology and environment (pp. 25-42). Dordrecht: Kluwer Academic Publishers. https://doi.org/ 10.1007/1-4020-3544-6_3

Hungria, M., Vargas, M. A. T., \& Campo, R. J. (1997). A inoculação da soja (Circular Técnica, 17, p. 28). Londrina: Embrapa.

Juliatti, F. C. (2010). Avanços no tratamento químico de sementes. Informativo Abrates, 20(3), 54-55.

Malavolta, E. (1980). Elementos de Nutrição Mineral de Plantas (p. 251). São Paulo: Ceres.

Menten, J. O., \& Moraes, M. H. D. (2010). Tratamento de sementes: histórico, tipos, características e benefícios. Informativo Abrates, 20(3), 52-71.

Miranda, C. H. B., \& Macedo, M. C. M. (2001). Fixação de nitrogênio pela soja em sistemas de cultivo contínuo e rotacionado com pecuária nos cerrados. Embrapa Gado de Corte.

Novais, R. F., Neves, J. C. L., \& Barros, N. F. (1991). Ensaio em ambiente controlado. In A. J. E. A. Oliveira (Ed.), Métodos de Pesquisa em Fertilidade do Solo (pp. 189-253). Brasília: Embrapa. 
Peske, S. T., Lucca, O. F., \& Barros, A. (2006). Sementes: Fundamentos Científicos e Tecnológicos (2nd ed., p. 470).

Santos, H. G. Dos, Jacomine, P. K. T., Anjos, L. H. C. Dos, Oliveira, V. A. De, Lumbreras, J. F., Coelho, M. R., ... Oliveira, J. B. De. (2013a). Sistema brasileiro de classificação de solos (3rd ed., p. 353). Brasília: Embrapa.

Santos, P. F., Silva, R. A., Costa, A. A., Cantelli, D. A. V., \& Martins, M. C. (2013b). Efeito do tratamento de sementes na nodulação e crescimento inicial da cultura da soja. Cultivando o Saber, 6(4), 96-108.

Silva, A. F., Schoninger, E. L., Monteiro, S., Caione, G., Carvalho, M. A. C., Dalchianon, F. C., \& Noetzold, R. (2011). Inoculação com bradyrhizobium e formas de aplicação de cobalto e molibdênio na cultura da soja. Revista Agrarian, 4(12), 98-104.

Soares, I. O., Rezende, P. M., Bruzi, A. T., Zambiazzi, E., V., Zuffo, A. M., Silva, K. B., \& Gwinner, R. (2015). Adaptability of soybean cultivars in different crop years. Genetics and Molecular Research, 14(3), 8995-9003. https://doi.org/10.4238/2015.august.7.8

Souza, V. Q., Follmann, D. N., Nardino, M., Baretta, D., Carvalho, I. R., Caron, B. O., ... Demari, G. H. (2015). Produção de sementes de soja e vigor das sementes produzidas com diferentes tratamentos de sementes. Global Science and Technology, 8(1), 157-166. https://doi.org/10.14688/1984-3801/gst.v8n1p157-166

Taiz, L., \& Zeiger, E. (2012). Fisiologia Vegetal (4th ed., p. 720). Porto alegre: Artmed.

Venegas, F., Tomazele, R., \& Farias, L. N. (2011). Efeito de diferentes produtos para tratamento de sementes no desenvolvimento inicial do algodoeiro (Gossypium hirsutum). Ensaios e Ciência, 14(1), 41-50.

Zuffo, A. M., Rezende, P. M., Bruzi, A. T., Oliveira, N. T., Soares, I. O., Neto, G. F., \& Silva, L. O. (2015). Coinoculação de Bradyrhizobium japonicum e Azospirillum brasilense na cultura da soja. Revista de Ciências Agrárias, 38(1), 87-93.

\section{Copyrights}

Copyright for this article is retained by the author(s), with first publication rights granted to the journal.

This is an open-access article distributed under the terms and conditions of the Creative Commons Attribution license (http://creativecommons.org/licenses/by/4.0/). 